\title{
Investigating the Methods of Management in Education with Taking the Case of a Teacher at the Stage of University
}

\section{Investigar los métodos de gestión en educación con tomar el caso de un profesor en la etapa universitaria}

\author{
Ekaterina V. Tulina \\ Nosov Magnitogorsk State Technical University, Magnitogorsk, Rusia \\ ORCID: https://orcid.org/0000-0003-3554-4545 \\ Maria V. Artamonova \\ Nosov Magnitogorsk State Technical University, Magnitogorsk, Rusia \\ ORCID: https://orcid.org/0000-0002-6332-8893 \\ Olga M. Sedliarova \\ Nosov Magnitogorsk State Technical University, Magnitogorsk, Rusia \\ ORCID: https://orcid.org/0000-0001-5063-1765

\section{Roman R.Vakhitov} \\ Nosov Magnitogorsk State Technical University, Magnitogorsk, Rusia \\ ORCID: https://orcid.org/0000-0002-2925-2426

\section{Svetlana S. Velikanova} \\ Nosov Magnitogorsk State Technical University, Magnitogorsk, Rusia \\ ORCID: https://orcid.org/0000-0002-3701-0494

\section{Oksana P. Chernykh} \\ Moscow University of Finance and Law MFUA, Moscú, Russia \\ ORCID: https://orcid.org/0000-0002-4439-0915
}

Recibido 17-10-19 Revisado 01-01-20 Aprobado 12-03-20 En línea 14-03-20

Correspondencia

Email: O.P.Chernykh@gmail.com
Citar como:
Tulina, E. V., Artamonova, M. V., Sedliarova, O. M., Vakhitov, R. R., Velikanova, S. S., \& Chernykh, O. P. (2020). Investigating the Methods of Management in Education with Taking the Case of a Teacher at the Stage of University. Propósitos y Representaciones, 8(3). doi: http://dx.doi.org/10.20511/pyr2020.v8n3.476

(C) Universidad San Ignacio de Loyola, Vicerrectorado de Investigación, 2020. 


\section{Summary}

The paper reveals the problem of the professional formation of a future teacher, training a teacher with a high intellectual level of self-awareness, being capable of conceptual thinking, creativity and being ready to independently managing one's own professional activity, which will allow interacting more effectively with the learning environment, being an active subject of professional and pedagogical activity.

Keywords: Reflexive Management; Professional Formation; Model; Reflection; Future Teacher.

\section{Resumen}

El documento revela el problema de la formación profesional de un futuro maestro, capacitar a un maestro con un alto nivel intelectual de autoconciencia, ser capaz de pensamiento conceptual, creatividad y estar listo para gestionar de forma independiente la propia actividad profesional, lo que permitirá interactuar más efectivamente con el ambiente de aprendizaje, siendo un sujeto activo de actividad profesional y pedagógica.

Palabras clave: Manejo reflexivo; Formación profesional; Modelo; Reflexión; Futuro Maestro

\section{Introduction}

\section{Introduction to the Problem}

The graduate school of education is faced with the task of preparing a teacher with a high intellectual level of self-awareness, being capable of conceptual thinking, creativity and being ready to independently manage one's own professional activities, which will allow interacting more effectively with the learning environment and being an active subject of professional and pedagogical activity. The school today needs such a teacher more than ever. The solution to these problems involves the creation of a flexible, open, varied education system, requires the pivot to new pedagogical technologies that ensure not only mastery by the future teacher of the accumulated large amount of knowledge but also the formation of one's ability to selfdevelopment and the ability to be ready to demonstrate one's essential forces.

\section{Topicality of the Problem}

Having regard to the above, the need for a complete reformation of educational sphere consists not only in a change in the pedagogical paradigm but also in a radical revision of its content and technological basis, as well as a change in values-based orientations in teacher education. The purpose of the article is the development, theoretical and praxeological substantiation, of experimental testing of the concept of reflexive management of the formation of the teacher tobe.

\section{Study of the Problem}

At present, productive approaches to theoretical and technological base for teacher education have been laid. The works by I. F. Isaev, N. V. Kuzmina, Y. N. Kulyutkin, A. I. Mishchenko, A. A. Rean, V. A. Slastenin, E. N. Shiyanov et al. (Isaev, 1993; Kuzmina, 1990; Kulyutkin, 1986; Mishchenko, 1992; Rean, 1990; Slastenin, 2000; Shiyanov, 1991) deal with this problem. There 
is an active process of studying the course of professional development of a specialist at the stage of university training.

Despite the fact that the system of higher pedagogical education has been developing intensively in recent years, it has a number of drawbacks, such as technological insecurity in the formation of professional activity, its focus on communicating acquired knowledge; a purely disciplinary nature of the educational process, authoritarian management style, the weakness of interdisciplinary relations; separation of the logic of assimilation of educational material from the upcoming professional activity; a poorly expressed professional and pedagogical direction of the educational process; incomplete use of the potential of the personal capabilities of the teacher-tobe. This leads to the fact that, having been educated within the traditional training framework, young teachers not only experience difficulties in mastering new technologies but are also psychologically not ready to work in the modern way. Naturally, this situation reinforced the need for finding new approaches not only in the very pedagogical education but also in determining the ways to improve the process of professional formation of the teacher-to-be at the stage of university training.

The above makes it possible to determine a number of contradictions between:

- the need of society for the development of a higher educational institution as a center of education, culture, science, new technologies and insufficiently developed theoretical foundations of the process of professional development of a student who does not have the necessary experience in combining management, co-management and self-management in mastering the profession;

- the objectively presented by the society to the teacher requirement of constant orientation in the problem of value self-determination, requiring one to be ready to reflect on one's place and purpose, and on the other hand, a standard teacher training system that does not create conditions that encourage value self-determination, the search for the personally important meaning of the profession, that is, it does not provide mastery of one of the most important social and professional functions - a reflexive functional analysis of pedagogical activity

- the declared requirements for the implementation realization of the abilities and potential capabilities of students and the need to ensure certain methods for such realization in the process of professional formation of students.

\section{Hypotheses}

The analysis of the scientific literature, educational programs and pedagogical practice shows that the formation of pedagogical attitudes to improve the quality of professional training of university students takes place (Isaev, 1993; Kulyutkin, 1986; Shiyanov, 1991). However, the above goals setting specifically and its realization does not guarantee an adequate result. It is understood that the goal setting itself and the degree of its achievement in pedagogical sciences (the connection between the goal setting and the degree of its achievement) are not clearly traced, therefore the results do not always coincide with the actual tasks set, this creates contradictions between the target prognostic settings of society and quality of the results obtained. And this, in turn, leads to the fact that the goal setting of professional training of the future teacher is in conflict with modern requirements for the final result of this training - the formed sphere of student's personal selfconstruction. Such contradictions can be resolved by introducing reflexive management of the student's professional development process. At the same time, the works we have analyzed cover only certain aspects of this problem, which suggests a lack of a holistic approach to solving it. 


\section{Methods}

For all the variety of modern studies of the problem of the professional formation of the future teacher, its focus on resolving the above shortcomings and contradictions, the necessary prerequisite for the professional formation and self-development of the teacher as a professional seems to be insufficiently studied - students reflects their own educational and cognitive and upcoming professional and pedagogical activities. Historical and logical analysis of this problem shows that for many years scholars did not want to see in the reflection of the teacher the urgent need of the individual, due to the laws of the professional formation of the teacher (Kulyutkin, 1986; Shiyanov, 1991).

Scholars began to actively raise and consider this problem, to develop the theory and technology of the reflexive-active organization of the educational process in higher education (Kuzmina, 1990; Mishchenko, 1992). It should be emphasized that the process of training a specialist cannot function effectively without involving reflective mechanisms, which at different stages of social organization contribute to the introduction of optimization adjustments in management processes. In this regard, the introduction of adjustments into the process of studying the disciplines of the humanitarian profile, and especially pedagogy, is of particular relevance.

This implies, on the one hand, the embodiment of the ideas of cultural identity and humanization, with the bringing of value knowledge with the formation of a socially demanded personality to the fore; on the other hand, the presence of a new educational paradigm within which these tasks would be solved. Removing this contradiction defines the problem of updating the content of the process of professional formation of the teacher-to-be.

\section{Results}

In accordance with the hypothesis of the study, the effective pedagogical support of the reflective control of the process of professional formation of the future teacher is ensured by the implementation of the provisions within the framework of the concept.

1. The professional formation of the future teacher is a developing, self-organizing system in which the interconnection of elements is determined not by static, but by dynamic factors based on modern approaches to self-organizing systems. This involves taking into account not only the foundations of the elements of the system but also the foundations of the activities of management entities at the stage of their university training.

2. Reflexive management of the process of professional formation of the future teacher is ensured by implementing a model, the development of which is based on the following ideas:

- the process of professional formation of future teachers is based on methodologically sound principles of reflexive management;

- the goals of reflexive management of the process of professional formation of the future teacher are subordinated to a reflexive analysis of the functional components of pedagogical activity;

- the content of the professional formation of the future teacher is built in the logic of their personal, semantic, reflexive development as the subjects of activity;

- intensifying technologies that include the technology of textually-figurative representation of pedagogical knowledge are the means of reflexive management of the process 
of professional formation of the future teacher; design technology for reflexive-pictographic tasks; game modeling technology.

3. The continuity and complementarity of educational-cognitive, educationalprofessional, research, simulation-modeling activities and pedagogical practice of the future teacher is ensured by the unity of methodological, theoretical, methodic, practical and reflexive training. Pedagogic disciplines in the practice of classical universities are human-forming disciplines and are carriers of general cultural knowledge.

4. Reflexive management of the professional formation of the future teacher is more efficient with the comprehensive observance of pedagogical conditions:

a) psychological and pedagogical support of the transition of management into selfmanagement by the process of becoming a personality of the future teacher;

b) self-actualization and inclusion of subjective experience (personal meanings) of the future teacher into the process of vocational training;

c) students' constructing the content of educational subjects of pedagogical disciplines via modeling;

d) teaching students to the composition and methods of synthesized solutions of reflexivepictographic pedagogical problems in a simulated situation and real professional pedagogical practice;

e) the use of game technology as an integrative way of reflexive management in the process of professional formation of the future specialist;

f) basic (dialectical unity of methodological, theoretical and technological) readiness of university teachers to implement reflexive management of the process of professional formation of the future teacher;

g) the focus of teacher education technology on the harmonization of integrative and differentiated processes in solving general and special problems in the course of the professional formation of the future teacher;

h) humanistically personality-oriented diagnosis and self-diagnosis of the process of professional development.

\section{Discussion}

The analysis of literature and pedagogical practice has allowed to conclude that there is an objective need for effective reflexive management of the process of professional formation of the future teacher. At the same time, we define the student's professional development as a purposeful, specially organized process of training of the student for pedagogical activity, the result of which is an integral, dynamic property of a person, which reflects one's professional orientation and expresses one's willingness to join in various types of pedagogical activity on the basis of reflexive-functional analysis.

When defining the concept of reflexive management, we proceed from the fact that reflexive management of the teacher's professional development process is a phased, dialogical, subject-subjective interaction, the content of which is intensifying student training technologies that contribute to the transition to self-directed development of the teacher-to-be. 
Consequently, the reflexive management of the process of professional formation of future teachers can be defined as follows - this is a purposeful, flexible interaction of the teacher with students, which develops on the basis of a phased transformation of the teacher and student positions into personality-equal positions of the collaborating individuals as a result of the realization of reflective principles and technologies that intensify learning.

Considering the features of managing the process of professional training of the future teacher, we single out such components of management as purposeful activity, organization, planning, leadership and feedback. Moreover, management should in its essence be guided by the personality of a student, teacher, leader.

The solution to the problem of reflexive management, in our opinion, is impossible without taking into account the requirements of such approaches as process, problem-oriented, systemic, situational, optimization, research, personal, cultural, synergistic, reflectivecomplementary. From the positions of these approaches, we single out and consider the features of the model of reflexive management of the process of professional formation of the future teacher.

Building a model of reflexive management involves the implementation of certain actions:

1. To consider the interaction and justify the relationship, through which reflexive management of the process of professional development of the student is possible.

2. To identify and justify the principles of reflexive management of the process of professional formation of the future teacher.

3. To identify the technology of intensifying training that contributes to the reflexive management of the process of professional formation of the future teacher.

4. To highlight the stages of reflexive management of the process of professional formation of the future teacher.

5. To provide feedback of the reflexive management of the process of student's professional development.

As a result of the experiment, we have achieved the goal of the study, verified the hypothesis and, on the whole, solved the tasks. We assess the level of effectiveness of our proposed model of reflexive management of the process of professional formation of the future teacher, taking into account the complex of identified pedagogical conditions as high. And the level of effectiveness of reflexive management is both effective and efficiently creative.

\section{References}

Bakholskaya, N. A. (2017). The Impact of Interactive Learning on the Development of the Professional Direction of Students of Pedagogical Specialties of a Higher Educational Institution. Humanitarian and Pedagogical Research. - Magnitogorsk: G.I. Nosov Magnitogorsk State Technological University Press, 1(1), 45-49.

Isaev, I. F. (1993). The Theory and Practice of the Formation of Professional and Pedagogical Culture of a Teacher of Higher Education. Moscow; Belgorod, p. 219.

Kulyutkin, Y. N. (1986). Creative Thinking in the Professional Activities of Teachers. Psychology Issues, 2, 21-30.

Kuzmina, N. V. (1990). Professionalism of the Personality of a Teacher and Master of Cooperative Education. M.: Higher School, p. 119.

Mikhina, O. V., \& Potrikeeva, E. S. (2018). On the Way to Finding New Methods of Teaching Foreign Languages (Analysis of Home and Foreign Experience). Prospects for Science and Education, 6(36), 155-163. 
Mishchenko, A. I. (1992). The Formation of a Teacher's Professional Readiness to Implement a Holistic Pedagogical Process. Author's Abstract of Dissertation for Doctor of Pedagogical Sciences. M., p. 32

Potrikeeva, E. S., Akhmetzyanova, T. L., \& Suvorova, E. V. (2018). Interconnected Teaching of Speaking and Reading in a Foreign Language at Non-Linguistic University. Modern Problems of Science and Education, 4, 70-76.

Rean, A. A. (1990). Reflexive-Perceptual Analysis in Teachers' Activities. Psychology Issues, 2 , 77-81-

Shiyanov, E. N. (1991). Theoretical Foundations of the Humanization of Teacher Education: Author's Abstract of Dissertation for Doctor of Pedagogical Sciences. M., p. 33

Slastenin, V. A. (2000). Higher Teacher Education in Russia on the Way of Reform. Pedagogy as a Science and as a Subject: Theses of International Science and Practice Conference (September 26-27, 2000) - Part 1. Tula: Tula State Pedagogical University Press, pp. 710 . 